\title{
Very high gravity ethanol fermentation by flocculating yeast under redox potential-controlled conditions
}

\author{
Chen-Guang Liư ${ }^{1}$ Na Wang ${ }^{1}$, Yen-Han Lin ${ }^{2 *}$ and Feng-Wu Bai ${ }^{{ }^{*}}$
}

\begin{abstract}
Background: Very high gravity (VHG) fermentation using medium in excess of $250 \mathrm{~g} / \mathrm{L}$ sugars for more than 15\% (v) ethanol can save energy consumption, not only for ethanol distillation, but also for distillage treatment; however, stuck fermentation with prolonged fermentation time and more sugars unfermented is the biggest challenge. Controlling redox potential (ORP) during VHG fermentation benefits biomass accumulation and improvement of yeast cell viability that is affected by osmotic pressure and ethanol inhibition, enhancing ethanol productivity and yield, the most important techno-economic aspect of fuel ethanol production.

Results: Batch fermentation was performed under different ORP conditions using the flocculating yeast and media containing glucose of $201 \pm 3.1,252 \pm 2.9$ and $298 \pm 3.8 \mathrm{~g} / \mathrm{L}$. Compared with ethanol fermentation by non-flocculating yeast, different ORP profiles were observed with the flocculating yeast due to the morphological change associated with the flocculation of yeast cells. When ORP was controlled at $-100 \mathrm{mV}$, ethanol fermentation with the high gravity (HG) media containing glucose of $201 \pm 3.1$ and $252 \pm 2.9 \mathrm{~g} / \mathrm{L}$ was completed at 32 and $56 \mathrm{~h}$, respectively, producing $93.0 \pm 1.3$ and $120.0 \pm 1.8 \mathrm{~g} / \mathrm{L}$ ethanol, correspondingly. In contrast, there were $24.0 \pm 0.4$ and $17.0 \pm 0.3 \mathrm{~g} / \mathrm{L}$ glucose remained unfermented without ORP control. As high as $131.0 \pm 1.8 \mathrm{~g} / \mathrm{L}$ ethanol was produced at $72 \mathrm{~h}$ when ORP was controlled at $-150 \mathrm{mV}$ for the VHG fermentation with medium containing $298 \pm 3.8 \mathrm{~g} / \mathrm{L}$ glucose, since yeast cell viability was improved more significantly.

Conclusions: No lag phase was observed during ethanol fermentation with the flocculating yeast, and the implementation of ORP control improved ethanol productivity and yield. When ORP was controlled at $-150 \mathrm{mV}$, more reducing power was available for yeast cells to survive, which in turn improved their viability and VHG ethanol fermentation performance. On the other hand, controlling ORP at -100 mV stimulated yeast growth and enhanced ethanol production under the HG conditions. Moreover, the ORP profile detected during ethanol fermentation with the flocculating yeast was less fluctuated, indicating that yeast flocculation could attenuate the ORP fluctuation observed during ethanol fermentation with non-flocculating yeast.
\end{abstract}

Keywords: Flocculating yeast, Very high gravity, Ethanol fermentation, Redox potential

\section{Background}

Fuel ethanol that is renewable and environmentally friendly has been produced around the world as an alternative to fossil fuels [1]. However, high production cost makes fuel ethanol heavily dependent on preferential policies and governmental subsidies, especially in the

\footnotetext{
* Correspondence: yenhan.lin@usask.ca; fwbai@dlut.edu.cn

${ }^{1}$ School of Life Science and Biotechnology, Dalian University of Technology, Dalian 116023, China

${ }^{2}$ Department of Chemical Engineering, University of Saskatchewan, Saskatoon SK S7N5A9, Canada
}

United States and China where fuel ethanol is produced mainly from grain-based feedstocks [2]. Since feedstock and energy consumption are the major cost, lignocellulosic biomass, due to abundance and low cost, particularly agricultural residues, has been intensively studied for the production of fuel ethanol, but challenges are to be addressed to make such a process economically competitive [3]. Meanwhile, very high gravity (VHG) fermentation can significantly increase ethanol titer in the fermentation broth, which not only saves energy consumption for ethanol distillation, but also reduces waste

\section{Biomed Central}


distillage discharged from the distillation system, and thus has garnered great attention [2].

Apparently, ethanol-tolerant strains are prerequisite for more efficient ethanol production under VHG conditions in order to overcome stuck fermentation, in which significant sugars are present at the end of fermentation, and ethanol yield, the most important techno-economic aspect of fuel ethanol production, is compromised, correspondingly. Stuck fermentation results from severe ethanol inhibition in yeast cells [2]. When yeast cells flocculate, they can be retained and immobilized within fermentors for high cell density to improve ethanol productivity [4]. Moreover, ethanol tolerance of yeast flocs can be improved, since the morphological change caused by the flocculation consequently affects physiological functions of yeast cell membranes and intracellular metabolism [5,6], making yeast flocs more suitable for VHG fermentation. However, in situ monitoring the growth of yeast flocs and their fermentation performance under VHG conditions presents a challenge, since dissolved oxygen in the fermentation broth is undetectable under micro-oxygen conditions.

Redox potential (ORP) reflects electron activities during fermentations, which provides real-time information on the physiological status of cells [7]. Controlling ORP during fermentations has thus been developed as an effective method to enhance the production of desired metabolites such as 1,3-propanediol, citric acid and xylitol [8-10]. Recent studies have shown that for VHG ethanol fermentation with non-flocculating Saccharomyces cerevisiae subjected to ORP control, high ethanol productivity and yield could be achieved [11-13].

In this study, ORP profiles were monitored and analyzed for ethanol fermentation with the flocculating yeast. Furthermore, ORP control strategy was developed by controlling ORP at two different levels in order to improve ethanol productivity and yield for VHG ethanol fermentation with the flocculating yeast.

\section{Results and discussion}

Time courses of ethanol fermentation by the flocculating yeast

ORP affected the growth of non-flocculating S. cerevisiae and ethanol fermentation under VHG conditions [11]. Thus, time courses of glucose consumption, ethanol production, biomass accumulation, mean size of yeast floc and ORP were monitored for ethanol fermentation with the flocculating yeast, in which three regions were identified and illustrated in Figure 1.

When yeast flocs were inoculated into fresh media, vigorous growth quickly depleted dissolved oxygen in the media and fermentation reducing power outperformed oxidizing power, leading to a drastic decline of ORP from $110 \mathrm{mV}$ to $-220 \mathrm{mV}$ in Region I, which was characterized by a logarithmic growth of yeast flocs.
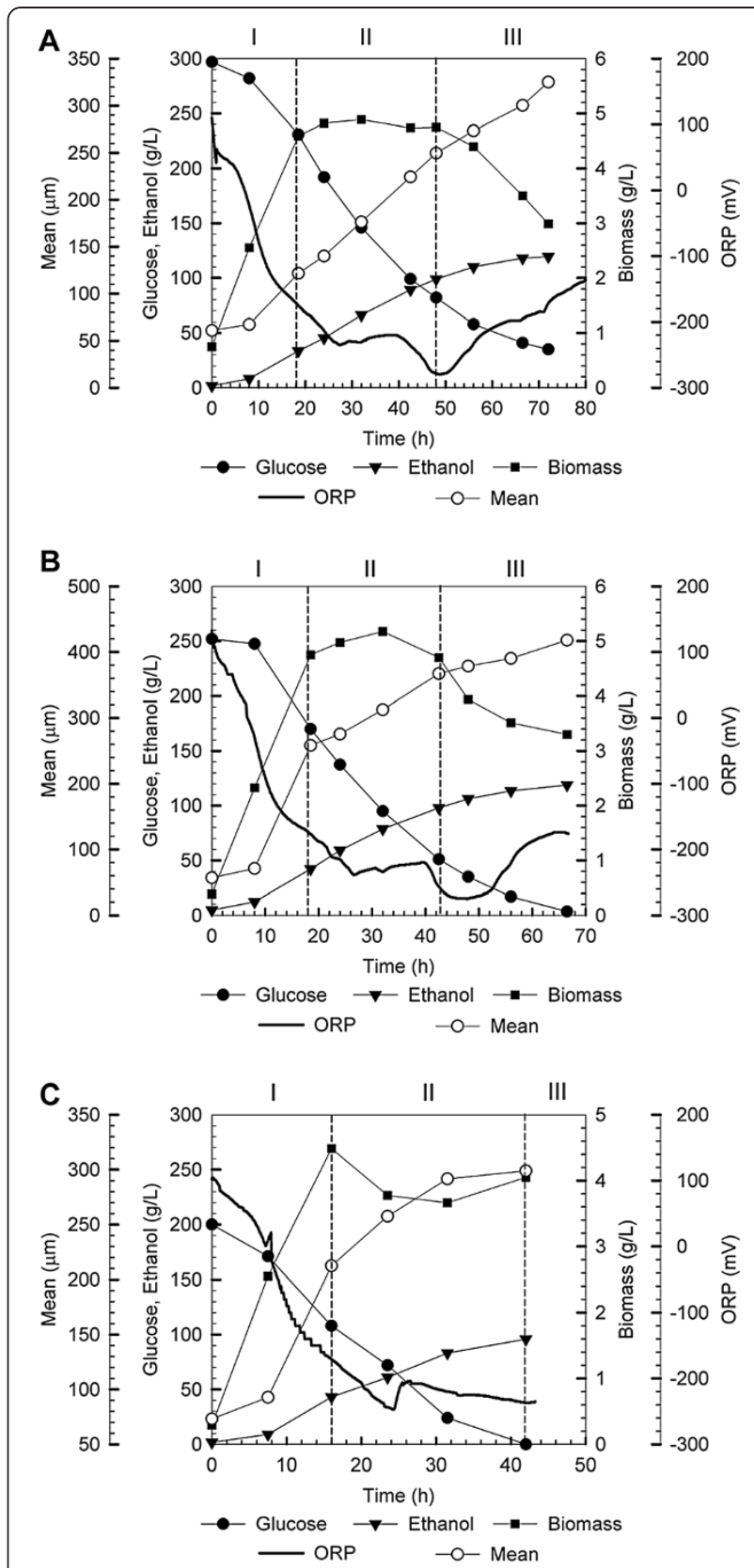

Figure 1 Ethanol fermentation by flocculating yeast without ORP control. Media containing glucose (g/L): $298 \pm 3.8$ (A), $252 \pm 2.9$ (B) and $201 \pm 3.1$ (C) Glucose consumption (solid cycle), ethanol production (solid triangle), biomass (solid square), ORP (bold line) and mean of yeast flocs (open cycle).

Yeast growth was then retarded due to ethanol accumulation and its inhibition effect, and a stationary phase was developed, correspondingly, which was characterized by a slow decrease of ORP till the lowest level of $-280 \mathrm{mV}$ in Region II. Near the end of fermentation, severe ethanol inhibition completely inhibited yeast growth, and in the meantime the lysis of yeast cells occurred, resulting in an increase of ORP. 
Compared with ethanol fermentation with nonflocculating $S$. cerevisiae [11], time courses of ORP and other parameters detected for ethanol fermentation with the flocculating yeast were different. On the one hand, no lag phase was observed for the growth of yeast flocs, which indicated that yeast flocculation provided protection for yeast cells to adapt to the rapid change of physiological environment after inoculated into the HG and VHG media. On the other hand, fermentation time was prolonged under the same glucose concentration and biomass accumulation conditions, indicating that mass transfer limitation occurred with yeast flocs, which was consistent with the increase of the mean size of yeast floc distribution from about $50 \mu \mathrm{m}$ detected at the beginning to about $250 \mu \mathrm{m}$ detected near the end of the fermentation.

Figure 1 also illustrates effect of different glucose concentrations during ethanol fermentation by the flocculating yeast where no ORP control was implemented. Under $201 \pm 3.1 \mathrm{~g}$ glucose/L conditions, it took $42 \mathrm{~h}$ to completely utilize glucose; whereas, it required $66 \mathrm{~h}$ for the case of $252 \pm 2.9 \mathrm{~g}$ glucose/L. Although the fermentation time was prolonged to $72 \mathrm{~h}$, there were $35.0 \pm 3.2 \mathrm{~g}$ glucose $/ \mathrm{L}$ remained unfermented under $298 \pm 3.8 \mathrm{~g}$ glucose/L conditions. The unfermented glucose not only compromises ethanol yield that is calculated based on total sugars feeding into fermentation systems without deduction of residual sugars, but also imposes difficulty for the subsequent treatment of waste distillage. Therefore, corresponding strategies should be developed to address these issues.

\section{Effect of ORP control on ethanol fermentation by the flocculating yeast}

Based on ORP profiles recorded in Figure 1 and previous studies on ethanol fermentation using non-flocculating yeast [11], two ORP levels at -100 and $-150 \mathrm{mV}$ were selected for ethanol fermentation by flocculating yeast under $201 \pm 3.1,252 \pm 2.9$ and $298 \pm 3.8 \mathrm{~g} / \mathrm{L}$ glucose conditions. Time courses of glucose consumption, ethanol production, biomass accumulation, mean size of yeast floc, and ORP were monitored and illustrated in Figure 2, and the experimental results were further summarized in Table 1.

In reference to ethanol fermentation without ORP control, more ethanol was produced when the ORP control strategy was applied. Since feedstock consumption is the major cost for fuel ethanol production [2], more ethanol production improved ethanol yield, and correspondingly saved feedstock consumption.

The highest ethanol concentration of $131.0 \pm 1.8 \mathrm{~g} / \mathrm{L}$ was obtained for ethanol fermentation with medium containing $298 \pm 3.8 \mathrm{~g} / \mathrm{L}$ glucose when ORP was controlled at $-150 \mathrm{mV}$. Whereas, for ethanol fermentation with media containing glucose of $252 \pm 2.9$ and $201 \pm 3.1 \mathrm{~g} / \mathrm{L}$, ethanol production was enhanced more significantly when ORP was maintained at $-100 \mathrm{mV}$.

Ethanol production is attributed to both yeast cell viability and biomass accumulation. Yeast cell viability was improved more significantly when ORP was controlled at $-150 \mathrm{mV}$, since more reducing power would favor the maintenance metabolism of yeast cells and correspondingly improve their viability $[14,15]$, which might be the main reason for the enhancement of ethanol production under the VHG condition. On the other hand, more biomass was accumulated when ORP was controlled at $-100 \mathrm{mV}$ during ethanol fermentation with media containing $201 \pm 3.1$ and $252 \pm 2.9 \mathrm{~g} / \mathrm{L}$ glucose. The increase of biomass concentration was due to more air sparged into the fermentation system (Table 1), which stimulated yeast propagation, and consequently improved ethanol production.

Glucose was completely consumed for ethanol fermentation with media containing $201 \pm 3.1$ and $252 \pm 2.9 \mathrm{~g} / \mathrm{L}$ glucose when ORP was controlled at $-100 \mathrm{mV}$. Although ethanol fermentation under $298 \pm 3.8 \mathrm{~g} / \mathrm{L}$ glucose conditions was improved when ORP was controlled at $-150 \mathrm{mV}$, as high as $24.0 \pm 1.1 \mathrm{~g} / \mathrm{L}$ glucose was remained unfermented, which would be not acceptable from the point of view of industrial application. Hence, various fermentation strategies and process configurations such as tanks-in-series fermentation systems have been developed $[16,17]$.

\section{Effect of yeast flocculation on ORP profile}

Compared with the bathtub ORP profile previously reported for VHG ethanol fermentation with $S$. cerevisiae [11], difference between the two ORP profiles (one with non-flocculating yeast, and another with flocculating yeast) was observed and illustrated in Figure 3.

Fluctuation in ORP during the stationary phase of non-flocculating yeasts was recorded. In contrast, ORP was relatively stable during ethanol fermentation with the flocculating yeast. We postulated that this difference might be due to the morphological change associated with the flocculation of yeast cells.

The flocculating yeast formed flocs during ethanol fermentation and the size of the yeast flocs increased as the fermentation proceeded (Figures 1 and 2). As more and more yeast cells flocculated together, a micro-environment was correspondingly developed among these cells. Yeast flocs are fragile in nature, and shear force induced by agitation breaks up larger flocs, and in the meantime smaller flocs re-flocculate and form large aggregates when they are in contact. As a result, metabolites occluded within yeast flocs and affecting ORP might release into the fermentation broth, and attenuate the ORP fluctuation observed in VHG ethanol fermentation with non-flocculating yeast. 


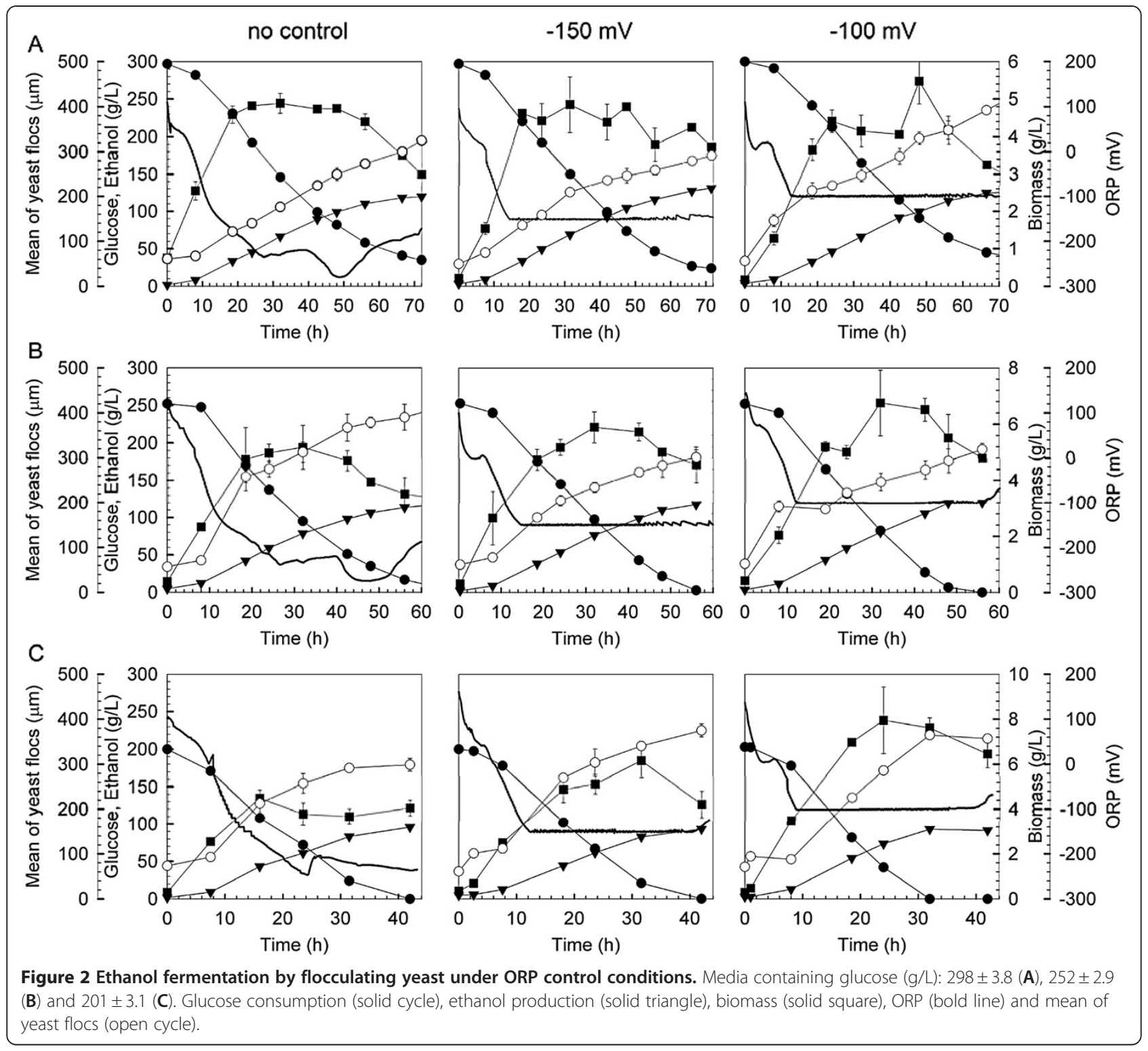

On the other hand, yeast flocculation also creates a physiological shelter to protect yeast cells from ethanol toxicity [18], as such the loss of yeast viability would be reduced (Table 1). It is noticed that there was no abrupt reduction of cell viability in the late stage of ethanol fermentation when the flocculating yeast was used; whereas, a sudden decline of yeast cell viability at the end of the stationary phase was reported during VHG ethanol fermentation when non-flocculating S. cerevisiae was employed [11].

\section{Conclusions}

Compared to non-flocculating yeast, no lag phase was observed for growth and ethanol fermentation of the flocculating yeast under VHG conditions, which resulted in a drastic decline of ORP, and in the meantime stuck fermentation with prolonged fermentation time and significant glucose remained unfermented was observed due to mass transfer limitation associated with the flocculation of yeast cells. The ORP control provided a strategy for improving ethanol productivity and yield for the VHG fermentation system.

Ethanol fermentation performance is affected by biomass accumulation as well as yeast cell viability, and thus the ORP control impacts the fermentation system differently. With media containing glucose of $201 \pm 3.1$ and $252 \pm 2.9 \mathrm{~g} / \mathrm{L}$, complete fermentation was observed at 32 and $56 \mathrm{~h}$ when the ORP was controlled at $-100 \mathrm{mV}$, since yeast cell growth was stimulated by more oxygen supply through aeration. On the other hand, for ethanol fermentation with medium containing $298 \pm 3.8 \mathrm{~g} / \mathrm{L}$ glucose, as high as $131 \pm 1.8 \mathrm{~g} / \mathrm{L}$ ethanol was produced at $72 \mathrm{~h}$ when the ORP was controlled at 
Table 1 Summary of the experiment results

\begin{tabular}{|c|c|c|c|c|c|c|c|c|c|c|}
\hline \multirow{2}{*}{$\begin{array}{l}\text { Redox } \\
\text { potential }(\mathrm{mV})\end{array}$} & \multirow{2}{*}{$\begin{array}{l}\text { Duration } \\
\text { (h) }\end{array}$} & \multicolumn{2}{|c|}{ Glucose (g/L) } & \multicolumn{2}{|c|}{ Ethanol (g/L) } & \multirow[t]{2}{*}{$Y_{\mathrm{PS}}(\mathrm{g} / \mathrm{g})$} & \multirow{2}{*}{$\begin{array}{l}\text { Productivity } \\
\text { (g/L/h) }\end{array}$} & \multirow{2}{*}{$\begin{array}{l}\text { Aeration } \\
(\mathrm{mL})\end{array}$} & \multirow{2}{*}{$\begin{array}{l}\text { Biomass } \\
(\mathrm{g} / \mathrm{L})\end{array}$} & \multirow{2}{*}{$\begin{array}{l}\text { Yeast } \\
\text { viability }{ }^{*}(\%)\end{array}$} \\
\hline & & Initial & Residue & Initial & Final & & & & & \\
\hline \multicolumn{11}{|c|}{$\sim 300 \mathrm{~g}$ (glucose)/L } \\
\hline-100 & & & $40.0 \pm 0.2$ & $4.1 \pm 0.3$ & $125 \pm 1.7$ & $0.466 \pm 0.02$ & $1.68 \pm 0.02$ & 1400 & $2.95 \pm 0.04$ & $49.25 \pm 2.81$ \\
\hline-150 & 72 & $298 \pm 3.8$ & $24.0 \pm 1.1$ & $3.2 \pm 0.1$ & $131 \pm 1.8$ & $0.467 \pm 0.01$ & $1.77 \pm 0.02$ & 200 & $3.13 \pm 0.14$ & $53.33 \pm 4.96$ \\
\hline No control & & & $35.0 \pm 3.2$ & $1.8 \pm 0.0$ & $119 \pm 1.5$ & $0.449 \pm 0.02$ & $1.63 \pm 0.02$ & 0 & $2.98 \pm 0.05$ & $35.21 \pm 4.21$ \\
\hline \multicolumn{11}{|c|}{$\sim 250 \mathrm{~g}$ (glucose)/L } \\
\hline-100 & & & $0.2 \pm 0.0$ & $3.8 \pm 0.3$ & $120 \pm 1.8$ & $0.461 \pm 0.03$ & $2.07 \pm 0.03$ & 6550 & $4.80 \pm 0.14$ & $50.00 \pm 4.68$ \\
\hline-150 & & & $3.1 \pm 0.1$ & $2.5 \pm 0.0$ & $117 \pm 2.2$ & $0.461 \pm 0.06$ & $2.05 \pm 0.04$ & 1230 & $4.55 \pm 0.64$ & $59.09 \pm 4.18$ \\
\hline No control & 56 & $252 \pm 2.9$ & $17.0 \pm 0.3$ & $4.9 \pm 0.3$ & $113 \pm 1.4$ & $0.462 \pm 0.04$ & $1.94 \pm 0.02$ & 0 & $3.51 \pm 0.58$ & $44.07 \pm 2.06$ \\
\hline \multicolumn{11}{|c|}{$\sim 200 \mathrm{~g}$ (glucose)/L } \\
\hline-100 & & & $0.0 \pm 0.0$ & $2.6 \pm 0.0$ & $93 \pm 1.3$ & $0.445 \pm 0.02$ & $2.82 \pm 0.04$ & 9220 & $6.45 \pm 0.60$ & $68.89 \pm 6.22$ \\
\hline-150 & 32 & $201 \pm 3.1$ & $21.0 \pm 0.2$ & $4.9 \pm 0.3$ & $83 \pm 1.4$ & $0.434 \pm 0.02$ & $2.43 \pm 0.04$ & 3120 & $4.20 \pm 0.60$ & $76.04 \pm 5.85$ \\
\hline No control & & & $24.0 \pm 0.4$ & $1.8 \pm 0.2$ & $83 \pm 1.5$ & $0.463 \pm 0.01$ & $2.54 \pm 0.05$ & 0 & $3.05 \pm 0.36$ & $65.00 \pm 13.3$ \\
\hline
\end{tabular}

"Data were collected at the end of fermentation.

$-150 \mathrm{mV}$, because the lower ORP level with more reducing power available for maintaining metabolism of yeast cells improved their viability more significantly. Although the ORP control improved ethanol fermentation performance, residual glucose was still high for the VHG ethanol fermentation, which would be not acceptable from the view point of industrial application, and other bioprocess engineering strategies such as tanks-in-series systems that can alleviate ethanol inhibition in yeast cells should be developed and integrated with the ORP control.

When ORP control was applied, the ORP profile detected during ethanol fermentation with the flocculating yeast was more stable, compared with that observed in ethanol fermentation with non-flocculating yeast, indicating that the morphological change associated with the flocculation of yeast cells and micro-environment created within yeast flocs not only attenuated the flocculation of ORP, but also might prevent yeast lysis, which would benefit process control and optimization.

\section{Methods}

\section{Yeast strain, media and ethanol fermentation}

The flocculating yeast strain was developed at Dr. Bai's lab at Dalian University of Technology [19]. This strain was cultured in the YPD medium composed of $(\mathrm{g} / \mathrm{L})$ : yeast extract, 4; peptone, 3; glucose, 30; to the mid-log phase (around $18 \mathrm{~h}$ ) in shake flasks, and inoculated into fermentor with $1 \mathrm{~L}$ working volume. The media contains $(\mathrm{g} / \mathrm{L})$ : yeast extract, 6 ; peptone, 8 ; along with three

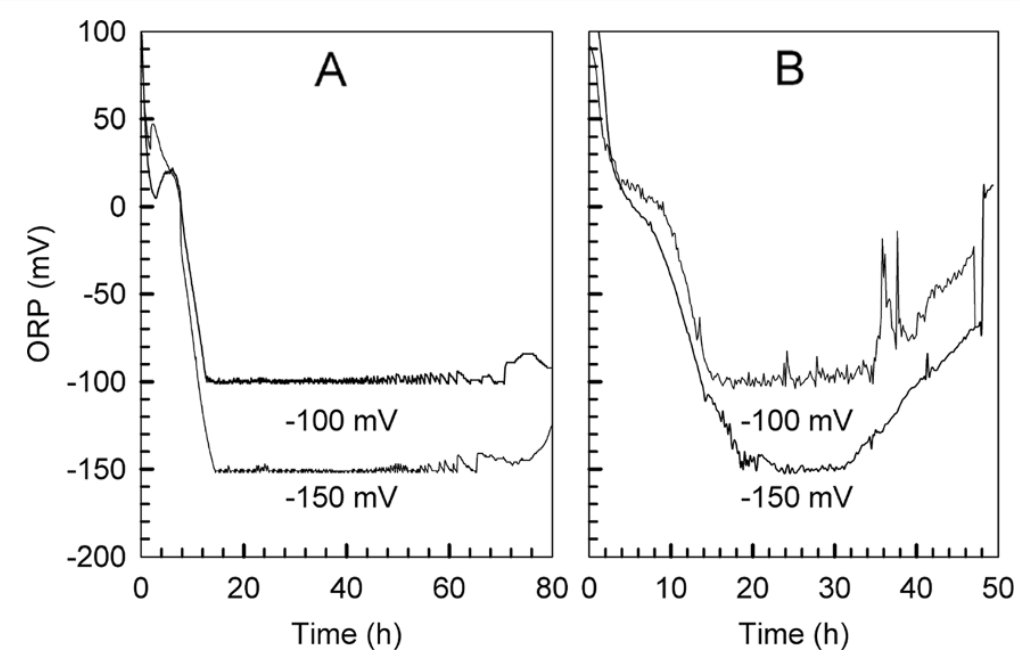

Figure 3 ORP profiles of ethanol fermentation by flocculating yeast (A) and non-flocculating yeast (B). Medium containing $~ 300 \mathrm{~g} / \mathrm{L}$ glucose and ORP controlled at -100 and $-150 \mathrm{mV}$, respectively. Data adapted from Lin et al. [11] for (B). 
different glucose concentrations: $201 \pm 3.1,252 \pm 2.9$ for high gravity fermentation, or $298 \pm 3.8$ for VHG fermentation. The inoculum level was $10 \%$ of the working volume. Temperature and $\mathrm{pH}$ were controlled at $30^{\circ} \mathrm{C}$ and 4.5 , respectively. The agitation rate was set at $150 \mathrm{rpm}$ for all runs.

\section{ORP control scheme}

An autoclavable ORP electrode (model: Pt4805-DPASSC-K8S/225, Mettler Toledo, Switzerland) was inserted into the fermentor to monitor ORP, and the measured voltage signal was processed by a pH/ORP controller (model: Transmitter PC-3100, Suntex, Taiwan). When the measured ORP was lowered than the set point, a proper amount of filter-sterilized $(0.2 \mu \mathrm{m}$ nylon membrane) air was sparged into the fermentor to maintain ORP at designated levels: -100 or $-150 \mathrm{mV}$. The amount of air was determined by the PID algorithm built-in in the $\mathrm{pH} / \mathrm{ORP}$ controller.

\section{Analysis}

A 4-mL fermentation broth was sampled every 6 or $8 \mathrm{~h}$. The sample was centrifuged at $10000 \times \mathrm{g}$ for $5 \mathrm{~min}$. The precipitate was washed twice with deionized water, dried at $85^{\circ} \mathrm{C}$ for $48 \mathrm{~h}$, and weighted. The supernatant was used to quantify glucose and ethanol by HPLC (Model: Waters $1525)$ with an RI detector (Model: Waters 2414). An ion exclusion column (Model: Aminex HPX-87 H $300 \times 7.8$ mm, Bio-Rad, USA) was used to separate metabolites. The mobile phase consisted of $10 \mathrm{mM} \mathrm{H}_{2} \mathrm{SO}_{4}$, and the flow rate was set at $0.6 \mathrm{~mL} / \mathrm{min}$. The temperature for column and RI detector were set at $50^{\circ} \mathrm{C}$. Yeast cell viability was determined as a ratio of viable to total cell numbers counted under microscope by methylene-violet staining procedure [20].

\section{Characterization of yeast flocs}

A focused beam reflectance measurement system was used to monitor yeast flocs in situ during the fermentation, which were characterized by the statistic mean of the yeast floc distribution [21].

\section{Abbreviations}

HG: High gravity; VHG: Very high gravity; ORP: Oxidation-reduction potential, also known as redox potential.

\section{Competing interests}

The authors declare that they have no competing interests.

\section{Authors' contributions}

CGL, under the supervision of YHL and FWB, developed the research scheme and prepared the draft manuscript. NW carried out the experimental work. CGL, YHL and FWB involved data interpretation, result discussion, and manuscript revision. All authors agreed and approved the manuscript submission.

\section{Authors' information}

CGL completed his PhD study on very high gravity ethanol fermentation in 2011 at Dalian University of Technology (DUT), China, and is now working as a post-doctoral fellow at DUT. NW is a MSC graduate at DUT, working on ethanol fermentation kinetics of flocculating yeast. YHL is a Professor at the Department of Chemical and Biological Engineering, University of Saskatchewan, Canada. FWB is a Professor at DUT's School of Life Science and Biotechnology. YHL and FWB co-supervised CGL's PhD study.

\section{Acknowledgments}

We appreciate the financial support by the National Natural Science Foundation of China (21276038) and China Postdoctoral Science Foundation Project (2012 M510809). We thank Dr. Wen-Jie Yuan and Dr. Alan K. Chang for their assistance with this work.

'School of Life Science and Biotechnology, Dalian University of Technology, Dalian 116023, China. ${ }^{2}$ Department of Chemical Engineering, University of Saskatchewan, Saskatoon SK S7N5A9, Canada.

Received: 28 May 2012 Accepted: 17 August 2012

Published: 24 August 2012

\section{References}

1. Solange IM, Dragone G, Guimaraes PMR, Silva JPA, Carneiro LM, Roberto IC, Vicente A, Lucilia: Technological trends, global market, and challenges of bio-ethanol production. Biotechnol Adv 2010, 28:817-830.

2. Bai FW, Anderson WA, Moo-Young M: Ethanol fermentation technologies from sugar and starch feedstocks. Biotechnol Adv 2008, 26:89-105.

3. Zhao XQ, Zi LH, Bai FW, Lin HL, Hao XM, Yue GJ, Ho NWY: Bioethanol from lignocellulosic biomass. Adv Biochem Eng Biotechnol 2012, 128:25-52.

4. Zhao XQ, Bai FW: Yeast flocculation: New story in fuel ethanol production. Biotechnol Adv 2009, 27:849-856.

5. Lei J, Zhao X, Ge X, Bai F: Ethanol tolerance and the variation of plasma membrane composition of yeast floc populations with different size distribution. J Biotechnol 2007, 131:270-275.

6. Xue C, Zhao XQ, Bai FW: Effect of the size of yeast flocs and zinc supplementation on continuous ethanol fermentation performance and metabolic flux distribution under very high concentration conditions. Biotechnol Bioeng 2010, 105:935-944.

7. Kjaergaard L: The redox potential: Its use and control in biotechnology. Adv Biochem Eng 1977, 7:131-150.

8. Berovic M, Cimerman A: Redox potential in submerged citric acid fermentation. Eur J Appl Microbiol Biotechnol 1982, 16:185-188.

9. Du C, Yan H, Zhang Y, Li Y, Cao Z: Use of oxidoreduction potential as an indicator to regulate 1,3-propanediol fermentation by Klebsiella pneumoniae. App/ Microbiol Biotechnol 2006, 69:554-563.

10. Sheu DC, Duan KJ, Jou SR, Chen YC, Chen CW: Production of xylitol from Candida tropicalis by using an oxidation-reduction potential-stat controlled fermentation. Biotechnol Lett 2003, 25:2065-2069.

11. Lin YH, Chien WS, Duan KJ: Correlations between reduction-oxidation potential profiles and growth patterns of Saccharomyces cerevisiae during very-high-gravity fermentation. Process Biochem 2010, 45:765-770

12. Liu CG, Lin YH, Bai FW: Development of redox potential-controlled schemes for very-high-gravity ethanol fermentation. J Biotechnol 2011, 153:42-47.

13. Yu Y, Wang YH, Chu J, Zhuang YP, Zhang SL: The influence of controlling redox potential on ethanol production by Saccharomyces cerevisiae. Chin J Biotechnol 2007, 23:878-884.

14. Draculic T, Dawes IW, Grant CM: A single glutaredoxin or thioredoxin gene is essential for viability in the yeast Saccharomyces cerevisiae. Mol Microbiol 2000, 36:1167-1174.

15. Wheeler $\mathrm{GL}$, Grant CM: Regulation of redox homeostasis in the yeast Saccharomyces cerevisiae. Physiol Plant 2004, 120:12-20.

16. Liu CG, Lin YH, Bai FW: Ageing vessel configuration for continuous redox potential-controlled very-high-gravity fermentation. J Biosci Bioeng 2011, 111:61-66.

17. Liu CG, Lin YH, Bai FW: Ageing vessel design and optimization for continuous very-high-gravity ethanol fermentation processes. Process Biochem 2012, 47:57-61.

18. Hu C, Bai FW, An L: Effect of flocculence of a flocculating yeast on its tolerance to ethanol and the mechanism. Chin J Biotechnol 2005, 21:123-128.

19. Zhao XQ, Li Q, He LY, Li F, Que WW, Bai FW: Exploration of a natural reservoir of flocculating genes from various Saccharomyces cerevisiae strains and improved ethanol fermentation using stable genetically 
engineered flocculating yeast strains. Process Biochem 2011, doi:10.1016/j. procbio.2011.06.009.

20. Smart KA, Chambers KM, Lambert I, Jenkins C, Smart CA: Use of methylene violet staining procedures to determine yeast viability and vitality. J Am Soc Brew Chem 1999, 57:18-23.

21. Ge XM, Zhao XQ, Bai FW: Online monitoring and characterization of flocculating yeast cell flocs during continuous ethanol fermentation. Biotechnol Bioeng 2005, 90:523-531.

doi:10.1186/1754-6834-5-61

Cite this article as: Liu et al.: Very high gravity ethanol fermentation by flocculating yeast under redox

potential-controlled conditions. Biotechnology for Biofuels 2012 5:61.

\section{Submit your next manuscript to BioMed Central and take full advantage of:}

- Convenient online submission

- Thorough peer review

- No space constraints or color figure charges

- Immediate publication on acceptance

- Inclusion in PubMed, CAS, Scopus and Google Scholar

- Research which is freely available for redistribution 